\title{
Comparison of Extraction Efficiency of Aqueous and Methanolic Extracts from Plant Tissues and Callus Cultures of Calotropis procera and Calotropis gigantea
}

\author{
Savita Rani, Gajendra Singh ${ }^{1}$ and Neelu Sood ${ }^{*}$ \\ Department of Botany, Kurukshetra University, Kurukshetra-136 119, India \\ Key words: Calotropis procera, C. gigantea, In vitro, Callus culture, Extraction \\ efficiency, Phyto-constituents.
}

\begin{abstract}
Extracts of plants may contain bioactive substances which could be used as natural antimicrobial agents against many microbes. Callus from the leaf material of Calotropis procera and C. gigantea was raised on different hormonal combinations and different extracts i.e. 50\% methanolic, $90 \%$ methanolic and aqueous extracts of leaf and callus were prepared. The extraction efficiency of different extracts of plant tissue and callus was calculated and compared. Callus tissue is advantageous over plant tissues for extraction of phyto-constituents for the basic reason that purification and isolation of active constituents are easier and also scale up strategies can be applied in vitro. Moisture content of tissue and the callus were analyzed and improved extraction efficiency was calculated after subtracting the moisture content.
\end{abstract}

\section{Introduction}

India is a biodiversity rich country. Since ancient times, plants are being used to prepare herbal remedies. Calotropis is a common medicinal plant with great medicinal potential which belongs to the family Asclepiadaceae. Calotropis procera and C. gigantea are two most common species of this genus. The therapeutic potential of Calotropis procera (Watt and Breyer-Brandwisk 1962, Kartikar and Basu 1994, Arya and Kumar 2005, Sehgal et al. 2006, Choedon et al. 2006) and Calotropis gigantea (Chitime et al. 2005, Wang et al. 2008, Saratha et al. 2009, Kumar et al. 2010) is very well documented. The two species are reported to contain various phyto-constituents (Akindele et al.2017, Chandrawat and

*Author for correspondence: <neelusood61@yahoo.com>. ${ }^{1}$ College of Pharmacy, Pt.B.D.S. University of Health Sciences, PGIMS, Rohtak-124 001, India. 
Sharma 2015, Shetty et al. 2015, Verma 2014, Meena et al. 2012, Agarwal et al. 2011) in all plant parts but little work has been done on phytochemical screening of the calli of Calotropis procera and C. gigantea. Callus is a potent source of phytoconstituents because laticiferous cell differentiation is minimal at this stage which is an interfering factor in plant based extractions. Callus culture can be advantageous over various plant tissues for phyto-constituent extractions. Callus cells have the advantage that cells with or without laticiferous tissue can be differentiated in vitro. The presence of latex causes contamination of certain unwanted compounds into pure phyto-constituents. This further leads to use of stringent purification techniques. Moreover, the differentiation of laticiferous cells can be regulated at will in vitro (Datta and De 1985). Additionally, literature is silent on the extraction efficiency of the plants which is a crucial step for plant based extractions. The moisture analysis is another important factor which is generally ignored. The present study deals with the comparison of extraction efficiency of tissue and callus extracts and standardization of most efficacious combination for callus culture of Calotropis gigantea (KUK/BOT/IPS-20) and C. procera (KUK/BOT/IPS-21). Aqueous and methanolic extractions were done for both the species and their moisture content was analyzed. Extraction efficiency was quantified and compared in both the species.

\section{Materials and Methods}

Leaves of Calotropis procera and C. gigantea were collected and washed thoroughly with running tap water and then with double distilled water. Ramenta from leaves were removed with cotton swab to avoid any contamination. Leaves were first air dried and then oven dried at $60^{\circ} \mathrm{C}$ for $12 \mathrm{hrs}$. Dried tissues were powdered in a grinder and kept in air tight polythene bags.

To minimize the error and to calculate the extraction efficiency of the plant material, moisture content was determined using moisture balance (AND, MX50). Observed moisture content has been shown in Table 2.

For Soxhlet extraction, tissue was wrapped in filter paper of high porosity.

To make the aqueous extract of the plant, $5 \mathrm{~g}$ of powdered material was mixed in $100 \mathrm{ml}$ of distilled water and was stirred on a magnetic stirrer for $3 \mathrm{hrs}$. The extract was filtered and the residue was again mixed in $100 \mathrm{ml}$. of distilled water. The extraction process was performed repeating 3 cycles and about $300 \mathrm{ml}$ of extract was formed.

To make $50 \%$ methanolic extract, $2 \mathrm{~g}$ of powdered sample were mixed with $150 \mathrm{ml}$ of $50 \%$ methanol and extracted using Soxhlet apparatus at $70^{\circ} \mathrm{C}$ for $50 \mathrm{hrs}$. 
To make $90 \%$ methanolic extract, $2 \mathrm{~g}$ of powdered sample were mixed with $150 \mathrm{ml}$ of $90 \%$ methanol and extracted using Soxhlet extractor at $70^{\circ} \mathrm{C}$ for $50 \mathrm{hrs}$.

The two species of Calotropis i.e. Calotropis procera and C. gigantea were obtained from the Horticultural Training Institute, Uchani, Karnal, Haryana. The in vitro cultures of these species were established using only the young leaves of the plants.

Fully expanded leaves (3rd leaf from top) and juvenile unexpanded leaves were collected from healthy and disease-free plants. The explants were washed thoroughly in tap water and ramenta (hairy growth) was removed with the help of fine brush without damaging the tissue. Sterilization was done in two steps: pre- and post sterilization. Pre sterilization was done outside the laminar air flow chamber and post sterilization was done inside the chamber. Explants were washed with a liquid detergent (Teepol) $(1 \%)$ for $10 \mathrm{~min}$ followed by thorough washing under running tap water for 5 - $10 \mathrm{~min}$ to remove any residue of the Teepol. These explants were then given different treatments before inoculation to minimize contamination in the culture. Sizing of explants $(1-2 \mathrm{~cm})$ was done under a laminar air flow chamber and those were finally inoculated to indifferent media. Juvenile leaves were inoculated without sizing.

The tissue culture experiment was performed using MS basal medium. The MS was supplemented with different concentrations of growth regulators, namely NAA, BAP, Kn, 2,4-D, IAA and their combinations as specified in Table 1.

Out of all these 13 combinations (MS $\left.-\mathrm{MS}_{12}\right), \mathrm{MS}_{8}$ i.e. $\mathrm{MS}_{0}+\mathrm{NAA}(2.5 \mathrm{mg} / \mathrm{l})+$ $\mathrm{Kn}(2.5 \mathrm{mg} / \mathrm{l})$ [coded as conc. A] and MS 11 i.e. MS + NAA (5 mg/l) + Kn (2.5 mg/l) [coded as conc. B] were found to be the best combinations for callus induction for both Calotropis procera and C. gigantea. Calli were raised in bulk using these combinations and extraction was done through Soxhlation.

Cultures were maintained at $25 \pm 2^{\circ} \mathrm{C}$ and provided with $16 \mathrm{hrs}$ of photoperiod (3000 lux intensity).

To prepare the 50 and $90 \%$ methanolic extracts of callus, the leaf callus was picked from the medium and washed with double distilled water to remove the traces of the media. The fresh weight of the callus was taken and then it was oven dried overnight at $50^{\circ} \mathrm{C}$. After taking the dry weight, the moisture content was determined using moisture balance shown in Table 3. The dried callus was wrapped in filter paper of high porosity and extracted with $150 \mathrm{ml}$ of 50 and $90 \%$ methanol, respectively using Soxhlet apparatus at $70^{\circ} \mathrm{C}$ for $50 \mathrm{hrs}$.

To prepare the aqueous extracts of callus, the leaf callus was picked from the medium and washed with double distilled water. The fresh weight of the callus was determined and it was crushed in double distilled water using pestle and 
mortar and raised to $100 \mathrm{ml}$. The weight and moisture content of the callus have been shown in Table 3.

Results of the experiments were analyzed using one way ANOVA (Tables 2, 3). It was found useful for determining whether there is a significant difference between the type of extraction solvent used for extraction of secondary metabolites and the value of extraction efficiency based on the type of species. SPSS (ver. 24, Chicago (IL) USA) was used for statistical analysis.

\section{Results and Discussion}

The extraction efficiency of leaf and callus of both the species i.e. Calotropis procera and C. gigantea was calculated (Tables 2 and 3). The comparison of the extraction efficiency of leaf and callus extract has been represented by the graphs (Figs 7, 8).

The extraction efficiency of the aqueous extracts of leaf of Calotropis gigantea was found to be maximum $(6.65 \pm 0.034 \%)$, followed by $90 \%$ methanolic extracts of leaf of Calotropis procera $(4.85 \pm 0.033 \%)$. The extraction efficiency was observed to be the minimum in aqueous extracts of Calotropis procera. The initial weight of dried sample, moisture content, weight of extract, initial extraction efficiency and final extraction efficiency of all the aqueous, 50 and $90 \%$ methanolic extracts of $C$. procera and $C$. gigantea have been compiled.

The extraction efficiency of $90 \%$ methanolic extracts of callus of Calotropis gigantea (on conc. B) was found to be maximum (43.86 $\pm 0.03 \%$ ) followed by $90 \%$ methanolic extracts of Calotropis procera $(23.86 \pm 0.03 \%)$ at concentration B. It was observed to be the minimum in aqueous extracts of Calotropis procera and $C$. gigantea on both A and B concentrations (less than 1\%). The initial weight of dried sample, moisture content, weight of extract, initial extraction efficiency and final extraction efficiency of all the aqueous, 50\% methanolic extracts and $90 \%$ methanolic extracts of Calotropis procera and C. gigantea on both A and B concentrations have been compiled in Table 3.

Extraction efficiency of methanolic extracts was found to be more than aqueous extracts. In both Calotropis procera and C. gigantea, concentration A i.e. $\mathrm{MS}_{0}+\mathrm{NAA}(2.5 \mathrm{mg} / \mathrm{l})+\mathrm{Kn}(2.5 \mathrm{mg} / \mathrm{l})$ showed higher extraction efficiency in $50 \%$ methanolic extracts but it was the highest in $90 \%$ methanolic extracts in case of $\mathrm{B}$ concentration i.e., $\mathrm{MS}_{0}+\mathrm{NAA}(5 \mathrm{mg} / \mathrm{l})+\mathrm{Kn}(2.5 \mathrm{mg} / \mathrm{l})$ for both the species.

Present results have also revealed that analyzing moisture content before the tissue/callus extraction is an important and significant step in plant based extractions. Tables 2 and 3 clearly indicate that $2-10 \%$ moisture content still remained in the tissue and callus even after drying it. 
Table 1. Showing different hormonal combinations in which callus was raised, intensity of callus and the type of callus.

\begin{tabular}{|c|c|c|c|c|}
\hline $\begin{array}{l}\text { Sr. } \\
\text { No. }\end{array}$ & $\begin{array}{l}\text { Type of } \\
\text { medium }\end{array}$ & $\begin{array}{l}\text { Hormonal } \\
\text { combination }\end{array}$ & $\begin{array}{l}\text { Intensity } \\
\text { of callus }\end{array}$ & $\begin{array}{l}\text { Type of } \\
\text { callus }\end{array}$ \\
\hline 1 & $\mathrm{MS}_{0}$ & MS basal & - & Explant discoloration \\
\hline 2 & $\mathrm{MS}_{1}$ & $\mathrm{MS}_{0}+\mathrm{IAA}(2 \mathrm{mg} / \mathrm{l})$ & - & Explant discoloration \\
\hline 3 & $\mathrm{MS}_{2}$ & $\mathrm{MS}_{0}+2,4-\mathrm{D}(2 \mathrm{mg} / \mathrm{l})$ & + & $\begin{array}{l}\text { Creamy, slow } \\
\text { growing callus }\end{array}$ \\
\hline 4 & $\mathrm{MS}_{3}$ & $\mathrm{MS}_{0}+2,4-\mathrm{D}(6 \mathrm{mg} / \mathrm{l})$ & ++ & $\begin{array}{l}\text { Creamy, slow } \\
\text { growing callus }\end{array}$ \\
\hline 5 & $\mathrm{MS}_{4}$ & $\begin{array}{l}\mathrm{MS}_{0}+\mathrm{IAA}(2 \mathrm{mg} / \mathrm{l})+2,4-\mathrm{D} \\
(2 \mathrm{mg} / \mathrm{l})\end{array}$ & - & Explant discoloration \\
\hline 6 & $\mathrm{MS}_{5}$ & $\begin{array}{l}\mathrm{MS}_{0}+2,4-\mathrm{D}(5 \mathrm{mg} / \mathrm{l})+\mathrm{Kn} \\
(2 \mathrm{mg} / \mathrm{l})\end{array}$ & + & $\begin{array}{l}\text { Creamy, slow } \\
\text { growing callus }\end{array}$ \\
\hline 7 & $\mathrm{MS}_{6}$ & $\mathrm{MS}_{0}+\mathrm{NAA}(2.5 \mathrm{mg} / \mathrm{l})$ & + & $\begin{array}{l}\text { Creamy, green, } \\
\text { profuse, friable callus }\end{array}$ \\
\hline 8 & $\mathrm{MS}_{7}$ & $\mathrm{MS}_{0}+\mathrm{NAA}(5 \mathrm{mg} / \mathrm{l})$ & ++ & $\begin{array}{l}\text { Creamy, green, } \\
\text { profuse, friable callus }\end{array}$ \\
\hline 9 & $\mathrm{MS}_{8}$ & $\begin{array}{l}\mathrm{MS}_{0}+\mathrm{NAA}(2.5 \mathrm{mg} / \mathrm{l})+\mathrm{Kn} \\
(2.5 \mathrm{mg} / \mathrm{l})\end{array}$ & +++ & $\begin{array}{l}\text { Creamy, green, } \\
\text { profuse, friable callus }\end{array}$ \\
\hline 10 & $\mathrm{MS}_{9}$ & $\begin{array}{l}\mathrm{MS}_{0}+\mathrm{NAA}(2.5 \mathrm{mg} / \mathrm{l})+\mathrm{Kn} \\
(1.25 \mathrm{mg} / \mathrm{l})\end{array}$ & +++ & $\begin{array}{l}\text { Creamy, green, } \\
\text { profuse, friable callus }\end{array}$ \\
\hline 11 & $\mathrm{MS}_{10}$ & $\begin{array}{l}\mathrm{MS}_{0}+\mathrm{NAA}(2.5 \mathrm{mg} / \mathrm{l})+\mathrm{Kn} \\
(1.75 \mathrm{mg} / \mathrm{l})\end{array}$ & +++ & $\begin{array}{l}\text { Creamy, green, } \\
\text { profuse, friable callus }\end{array}$ \\
\hline 12 & $\mathrm{MS}_{11}$ & $\begin{array}{l}\mathrm{MS}_{0}+\mathrm{NAA}(5 \mathrm{mg} / \mathrm{l})+\mathrm{Kn} \\
(2.5 \mathrm{mg} / \mathrm{l})\end{array}$ & +++ & $\begin{array}{l}\text { Creamy, green, } \\
\text { profuse, friable callus }\end{array}$ \\
\hline 13 & $\mathrm{MS}_{12}$ & $\begin{array}{l}\mathrm{MS}_{0}+\mathrm{BAP}(1 \mathrm{mg} / \mathrm{l})+\mathrm{NAA} \\
(2.5 \mathrm{mg} / \mathrm{l})\end{array}$ & + & $\begin{array}{l}\text { Explant discoloration, } \\
\text { callus initiation }\end{array}$ \\
\hline
\end{tabular}

On comparing the extraction efficiency of leaf and callus extracts, it was observed that callus extracts have more extractive value than leaf extracts which implies that the amount of secondary metabolites synthesized by the plant in vitro is more than in vivo. Callus extraction for phyto-constituents and its antimicrobial activity in different plants have been reported earlier by many workers (Arafa et al. 2016, Bhagya and Chandrashekar 2013, Jadhav et al. 2013, Singh 2011) but no such work has been reported previously on Calotropis procera and C. gigantea. 


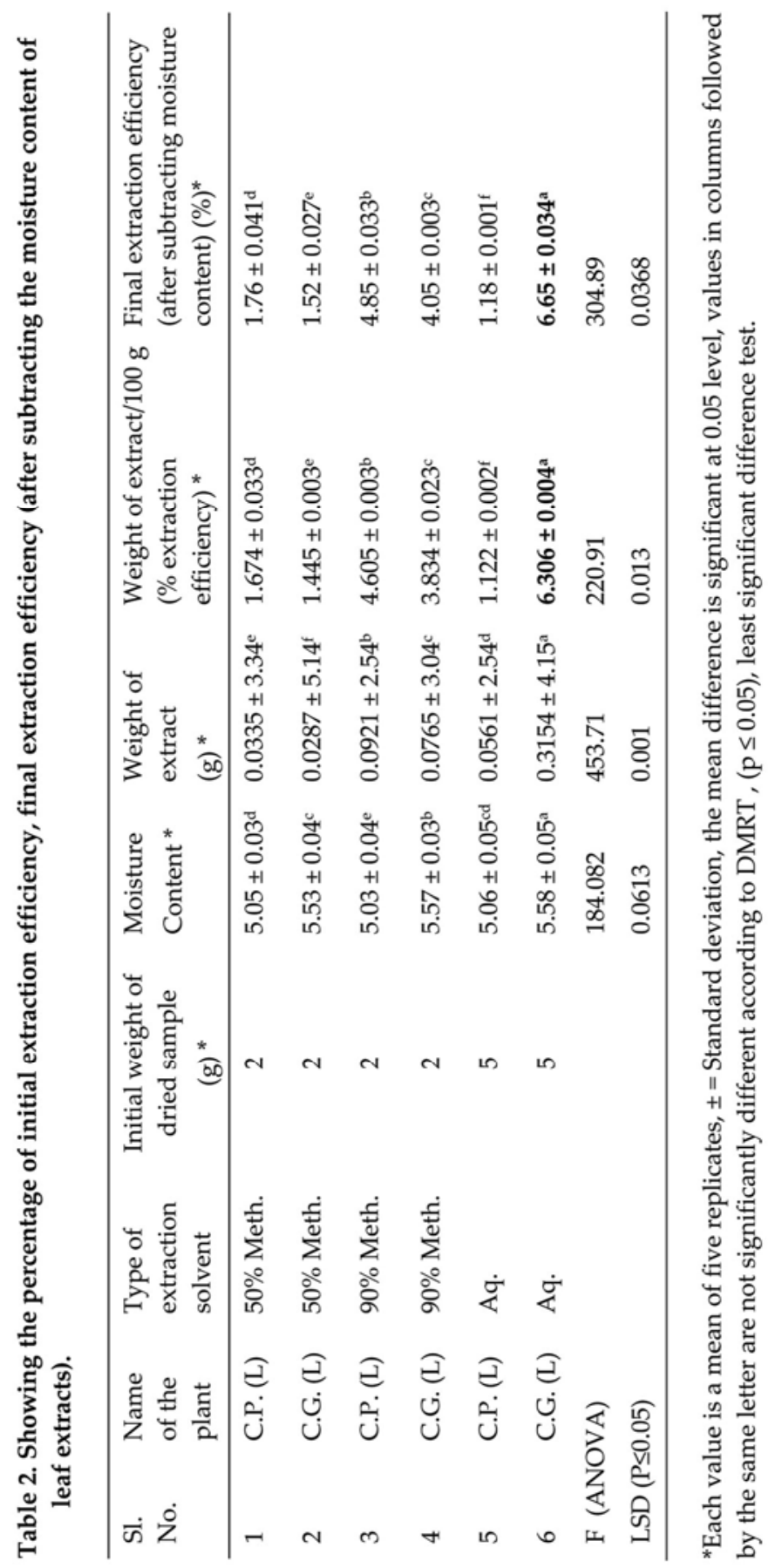




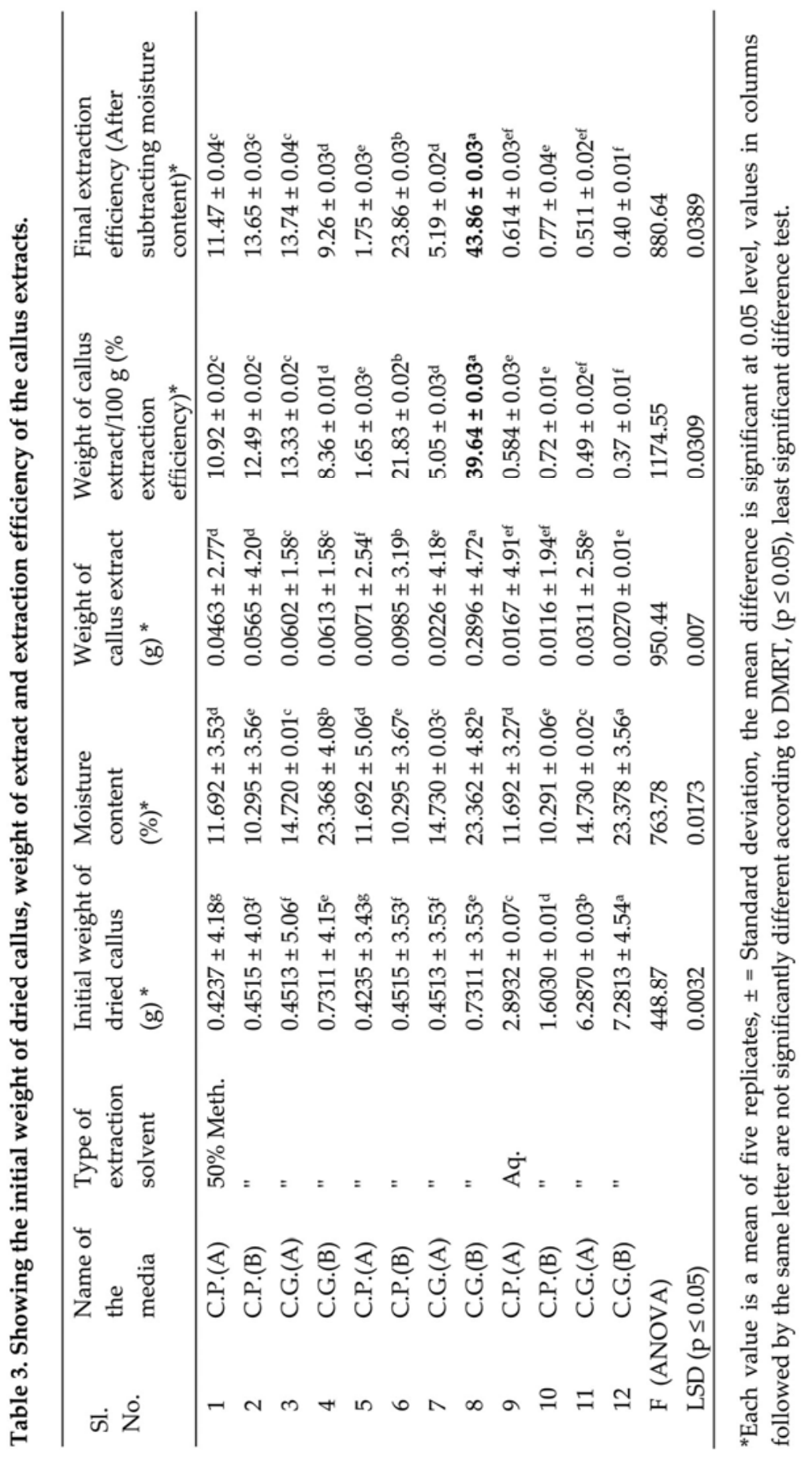



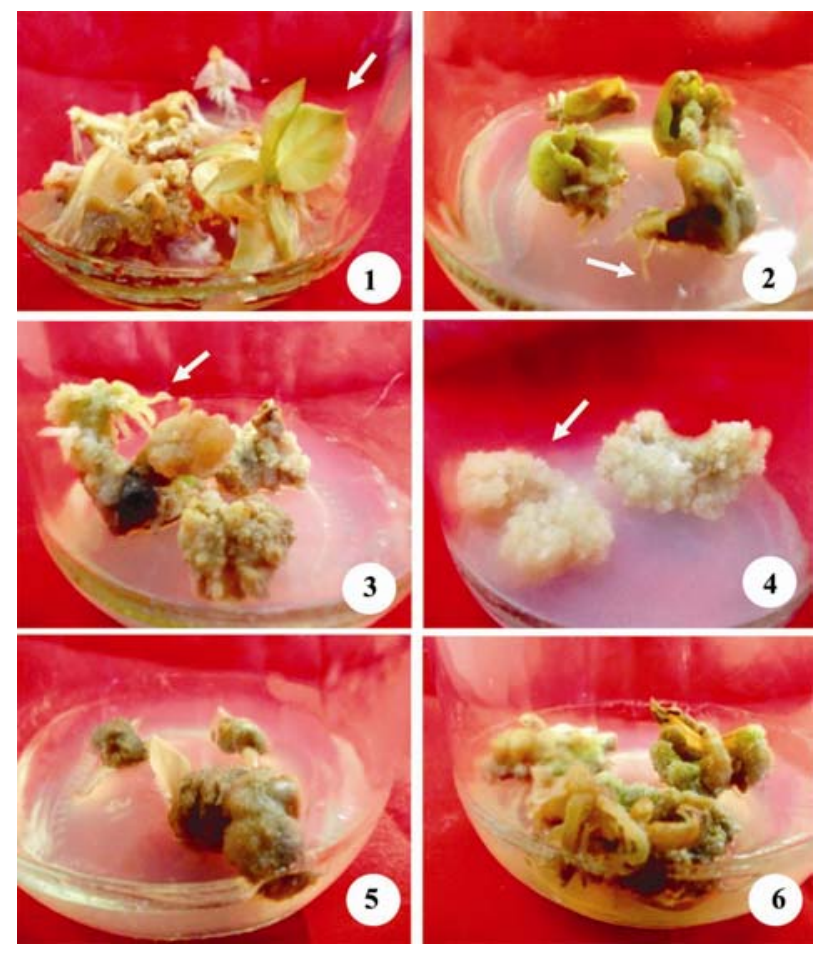

Figs 1-6. Showing callus proliferation of Calotropis procera and C. gigantea on different media: 1. Callus initiated from juvenile leaves of Calotropis procera on conc. A (MS ${ }_{0}+\mathrm{NAA}(2.5 \mathrm{mg} / \mathrm{l})+\mathrm{Kn}(2.5 \mathrm{mg} / \mathrm{l})$. 2. Callus initiated from leaf segment of Calotropis procera on B conc. (MS $\mathrm{M}_{0}+\mathrm{NAA}(5 \mathrm{mg} / \mathrm{l})+\mathrm{Kn}(2.5$ $\mathrm{mg} / \mathrm{l})$ 3. Callus initiated from leaf segment of Calotropis gigantea on A concentration. 4. Callus initiated from leaf segment of Calotropis gigantea on B concentration. 5. Callus initiated from leaf segment of Calotropis procera on 2,4-D (6 mg/l). 6. Callus initiated from leaf segment of Calotropis gigantea on $2,4-\mathrm{D}(6 \mathrm{mg} / \mathrm{l})$.

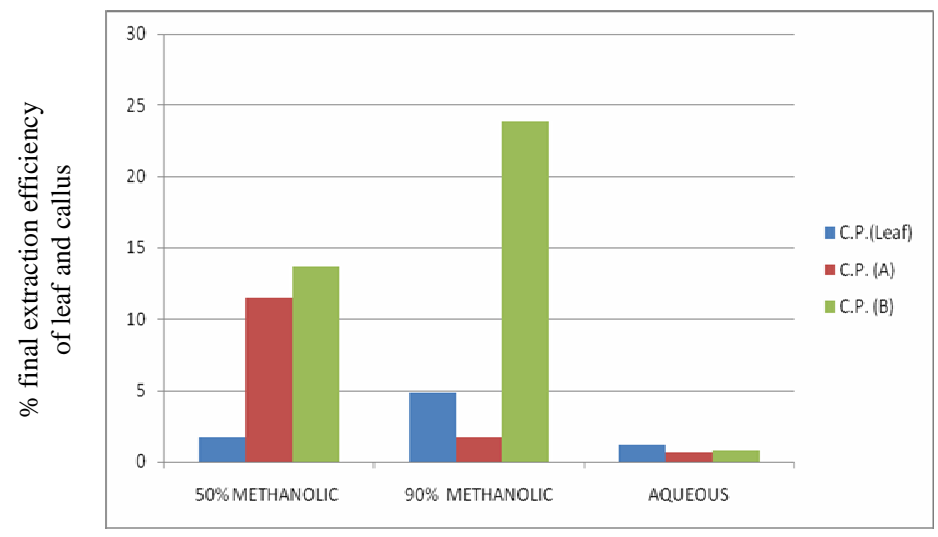

Type of extract

Fig. 7. Showing the comparison of extraction efficiency of different extracts of leaf and callus of Calotropis procera. 


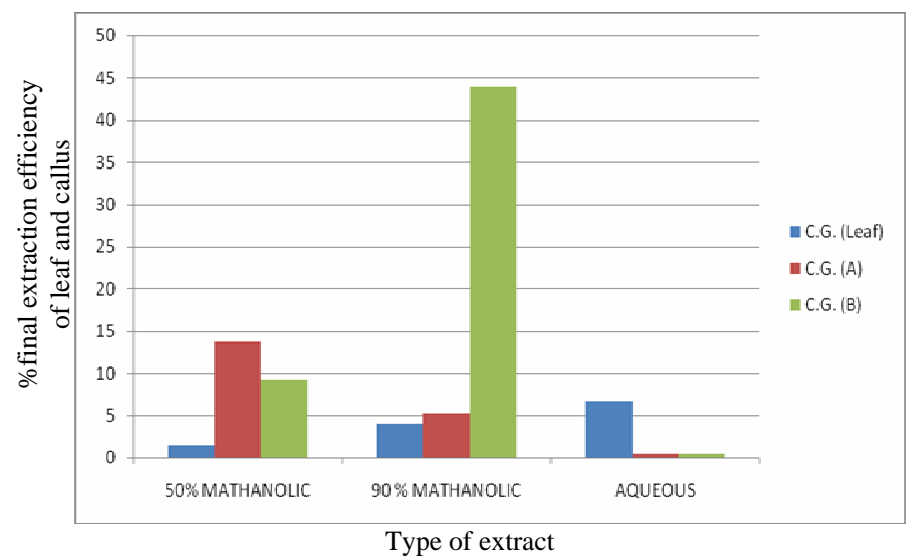

Fig. 8. Showing the comparison of extraction efficiency of different extracts of leaf and callus of Calotropis gigantea.

Callus cells are easily dissociable as they lack heavy cell wall depositions. In comparison, cell to cell compaction is very high in intact tissues and tissue dissociation requires treatment with a lot of mechanical and chemical tissue maceration methods. In our experimental observations, comparison between plant tissue and callus tissue showed a very significant increase in extraction efficiency. The type of tissue was found to be the governing factor of the above said parameters. The present study strengthens the fact that calculation and deduction of moisture content is important in extraction to enhance its extraction efficiency to a measurable extent.

\section{References}

Agarwal A, Singh N, Kannojia P and Garg VK (2011) Pharmacological aspects of Calotropis gigantea on various health problems: A Review. IJAPR 2(12): 613-620.

Akindele PO, Fatunla OA, Ibrahim KA and Afolayan CO (2017) Antibacterial and phytochemical screening of calotropis procera leaf extracts against vancomycin and methicillin resistant bacterial isolated from wound samples in hospital patients. J. Altern. Complement Med. 2(1): 1-14.

Arafa NM, Mohamed SS and Aly UI (2016) In vitro antimicrobial activity of carrot callus extracts as affected by tyrosine and tryptophan precursor. Int. J. Pharm. Tech. Res. 9(9): 121-129.

Arya S and Kumar V (2005) Anti- inflammatory efficacy of extracts latex of Calotropis procera against different mediators of inflammation. Mediat. Inflamm. 4: 228- 232.

Bhagya N and Chandrashekar KR (2013) Evaluation of plant and callus extracts of Justicia gendarussa Burm. F. for phytochemical and antioxidant activity. IJPPS. 5(2): 82-85. 
Chandrawat P and Sharma RA (2015) GC-MS Analysis of fruits of Calotropis procera: A medicinal shrub. Res. J. Recent Sci. 4: 11-14.

Chitime HR, Chandra R and Kaushik S (2005) Evaluation of antipyretic activity of Calotropis gigantea (Asclepiadaceae) in experimental animals. Phytother. Res. 19: 454456.

Choedon T, Mathan G, Arya S, Kumar VL and Kumar V (2006) Anticancer and cytotoxic properties of the latex of Calotropis procera in a transgenic mouse model of hepatocellular carcinoma. World J. Gastroenterol. 12: 2517-2522.

Datta S K and De S (1985) Laticifer differentiation of Calotropis gigantea R. Br. ex Ait. in cultures. Ann. Bot. 57: 403-406.

Jadhav VD, Bhanuwanshe SM, Patil SP, Chaudhari DV and Adke MB (2013). Antibacterial activity of different plant and callus extracts: A comparative study. IJSTR 2(10): 285- 288.

Kartikar KR and Basu BD (1994) Medicinal properties of neem: New findings. Indian Medicinal Plants, Allahabad, India 3(2). 1606-1609.

Kumar G, Karthik L and Bhskara Rao KV (2010) In vitro anti candida activity of Calotropis gigantea. J. Pharm. Res. 3(3): 539-542.

Meena AK, Yadav A and Rao MM (2012) Ayurvedic uses and pharmacological activities of Calotropis procera Linn. Asian J. Tradit. Med. 6(2): 45-53.

Saratha V, Subramanian S and Sivakumar S (2009) Evaluation of wound healing potential of Calotropis gigantea latex studied on excision wounds in experimental animals. Med. Chem. Res. 10: 9240-9246.

Sehgal R, Roy S and Kumar V (2006) Evaluation of cytotoxic potential of latex of Calotropis procera and podophyllotoxin in Allium cepa model. Biocell. 30: 9-13.

Shetty VG, Patil MG and Dound AS (2015). Evaluation of Phytochemical and antibacterial properties of Calotropis procera (Ait.) R. Br. leaves. IJPPS 7 (4): 316-319.

Singh CR (2011). Antimicrobial effect of callus and natural plant extracts of Premna serratifolia L. IJPBR 2(1): 17-20.

Verma VN (2014) The chemical study of Calotropis. ILCPA 1: 74-90.

Wang Z, Wang M, Mei W, Han Z and Dai H (2008) A new cytotoxic pregnanone from Calotropis gigantea. Molecules 13: 3033-3039.

Watt JM and Breyer-Brandwisk MG (1962) Medicinal and poisonous plants of Southern and Eastern Africa. 